\title{
The Udmurt Pantheon and the Udmurt Worldview
}

\author{
Tatiana Vladykina \\ e-mail: tgvladykina@mail.ru
}

\begin{abstract}
The research gives an overview of the Heavenly (in/inma/ immu/inmu, lit: 'heaven/heavenly earth') area, its construction, and its gods. Udmurt narratives about the creation of the world are related to biblical subjects and images. In their folklore we find the image of a heavenly stove and heavenly table, i.e. the constellation of Ursa Major. The supreme deities include the creator God (Inmar, Kuaz', Kyldys'in/ Kylchin) and the female deities (Kaldyk-mumy/Kaltak, Shundy-mumy, "Mother-Sun / Mother of the Sun", Invu-mumy "Mother of Heavenly Water / Heavenly Grace", Invozho-mumy "Mother-Invozho, Goddess of Summer Feast Time, i.e. Transitional Time", Gudyri-mumy, ThunderMother, Muz"yem-mumy, Mother-Earth).
\end{abstract}

Keywords: heaven, heavenly gods, Inmar, Invozho, Udmurt mythology

The Udmurt conception of the world (dun'n'e) is not always formed into detailed and complete stories. One of the possible ways to reconstruct mythological concepts is to use language in all its forms of expression from the everyday to the ritual. The richest source can be the language of folklore, from the point of view of sustainable images, which in their entirety are revealed only in the context of the rite. Restoration of contextual connections of the rite itself, 
in turn, allows the reconstruction of the spatio-temporal parameters of the world model, filling it with meaning and highlighting its individual components, the aggregate-holistic meaning of which is often hidden even from the bearers of traditions. Sources of research, therefore, are texts of completely different levels: speech units in the form of separate words, expressions, motifs and other genres with complete plots; attributive ritual texts, everyday behavioural stereotypes. To a great extent, the tradition of spells 'preserved' archaic conceptions because of the sacredness of the language and the possibility of maintaining different time layers. A whole layer of information about the Udmurt conception of the world can also be obtained from beliefs, the system of the most important requirements covering the entire lifecycle and regulating the information about the social and natural environment of a person at his or her most important spatio-temporal levels.

Implicit information about the relict, diatomaceous, vertical two-part earth can be found in the nominations of heaven and earth. Heavenly (in/inma/immu/inmu, lit: 'heaven/heavenly earth') and earthly areas are perceived as similar. Both areas have a bottom: mu pydes / the bottom of the earth, and in pydes / the bottom of heaven. There are also conceptions of a multi-layered earth in kuin'/siz'ym mu pydes, the third/seventh bottom of earth. The concept of pydes/bottom corresponds with the bottom of the water (vu pydes) and river bottom (shur pydes), which creates the idea of water $(v a / v u)$ as a cosmic, universal body that surrounds earth and heaven.

The commonly used word inbam/skyline (lit: 'heavenly cheek') replaced the word ingur/firmament, also meaning skyline. The pronunciation of this last word served as the basis for the mythological perception of the sky as a heavenly stove. Riddles have generally preserved this image, for example in Ingur ulyn tshuzh chipy Shundy (Under the heavenly stove there is a yellow chicken (the Sun)); Chil'tyrtis'koz, voshtis'koz - in gur ule suz'tis'koz - Vuyuis' (Well-dressed and beautiful, sitting under the heavenly stove (the 
Rainbow)). The perception of the sky as a stove is also preserved in riddles about the moon and stars, although here the word heavenly is missing: Gur tyros perepech, shoraz odig n'an' koldy / shanga (The stove is full of cheesecakes and in the middle there is a loaf of bread), Gur ulyn tshuzh chipi vetle (Under a stove there is a chick) (Perevozchikova 1982: 214-216). Along with the image of a heavenly stove, there is an image of a heavenly table as a heavenly altar, which is hidden in the word that means Ursa Major ([In] dzhökkuk kiz'ili, lit: Stars are the legs of the [heavenly] table). The images of a heavenly and an earthly stove, a heavenly table and an earthly table are continued by dichotomous parallels of spells containing images of the heavenly sun and the earthly sun, as well as the heavenly and the earthly stars.

The well-known rite entitled 'travelling to heavenly earth' (immala-vetlon) takes place during the summer solstice when pilgrims travel to places of worship, marked with birch trees and a spring (Vladykina 2004: 10). The word inma has served as the basis for the conception of Inmar, the God who rules heaven. This can be seen in the expression inmare tubyny / climb up to Inmar, meaning climb up to heaven; inmar zore / it is raining, lit: 'heaven is raining'. Under the influence of Christianity, Inmar began to be perceived as Jesus Christ or God the Father.

As with Inmar, the formation of another deity image has occurred. The concept of atmosphere, weather/kuaz' has grown into the deity named Kuaz'. The expression zore ('it is raining', lit: 'rains') is similar to kuaz' zore ('the sky is raining', lit: 'the God named Kuaz' has sent the rain'). According to belief, Kuaz' is awake during the day, but sleeps at night, therefore, you cannot mention him in the evening: Kuaz'ez dzhytaz'e verany ug yara: Kuaz' iz'e $n ' i$ ('You cannot talk about Kuaz' in the evening, because he is already sleeping'). Kuaz' rules the bee swarms, he is worshipped when hives are carried. People say about him mush ishtys'-kosys' 'sending and leading bees'. His evolution is connected with the wood spirit (n'ulesmurt) and St Nicholas. 
Inmar and Kuaz'together with the creator God (Kyldys'in / Kylchin; from Udmurt kyldytis', creating, creator) have formed a triad of supreme deities. Kyldys'in helps livestock births, patronises human births, children (Nuny-Kylchin); later he became the god of fertility (Mu-Kyldys'in). According to legend, in ancient times he lived among people, walking through fields as an old man in white clothes, looking after the crops. But he was offended by the disobedience of people and left them. People have begged him to return, he acceded to their appeals and has appeared on the holy birch in the form of a squirrel. People wanted to keep him forever and shot the squirrel, but it turned into a hazel grouse, the hazel grouse turned into a black grouse, and that grouse into a perch that hid in the river. Since then, according to legend, the Udmurt keep images of Kyldys in (wood chips, squirrel skin, hazel grouse wing, black grouse wing, dried fish) as relics. These items made up the content of the vorshud box in the clan sanctuary, the kua.

The female hypostasis of Kyldys'in is Kaldyk Mumy / Kaltak, one of the great mothers along with Shundy-mumy (Mother-Sun / Mother of the Sun), Invu-mumy (Mother of Heavenly Water / Heavenly Grace), Invozho-mumy (Mother-Invozho, Goddess of Summer Feast Time, i.e. Transitional Time), Gudyri-mumy (ThunderMother), Muz"yem-mumy (Mother-Earth).

It might seem that the list of deities is chaotic, as it resulted from various multi-temporal layers. However, it highlights an important detail: the deification of natural phenomena (sky, weather, sun, thunder, earth, rain) is replaced with deification of the creation process, as exemplified by the appearance of Inmar-Kylchin, whose ancestor is Grand Mother Kaltak, a name that shows typological parallels with the Mari and Ob-Ugric people. Today Inmar-Kylchin is one of the images of Jesus Christ, in linguistic expression a synonym, often a guardian angel (Vladykin 1994: 181-183).

Attention to the image is already found in the first written sources, i.e. travellers' notes from the end of the $18^{\text {th }}$ century (Georgi, Pallas, Messerschmidt), as well as a lot of evidence 
The Udmurt Pantheon and the Udmurt Worldview

Invu-mumy. Computer generated image. Made by Ulyana

Konstantinova (2021).

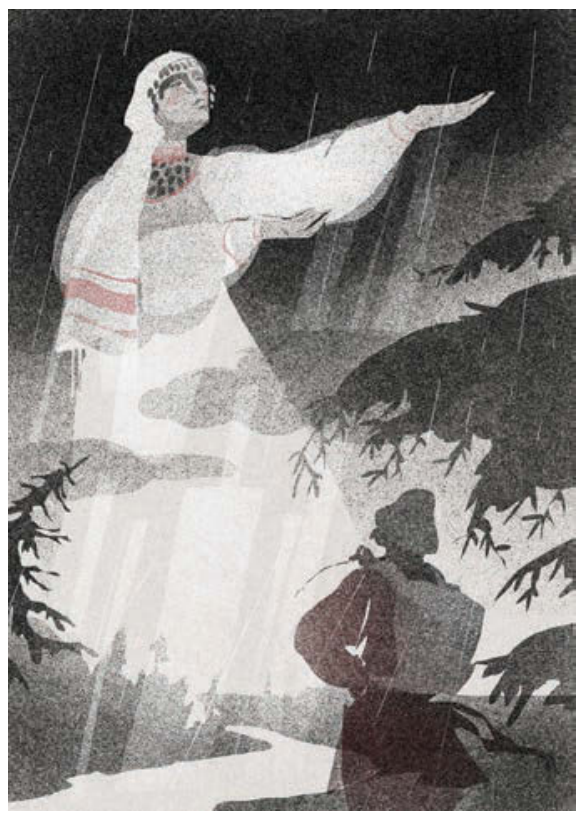

Kyldys'in. Computer generated image. Made by Ulyana

Konstantinova (2021).

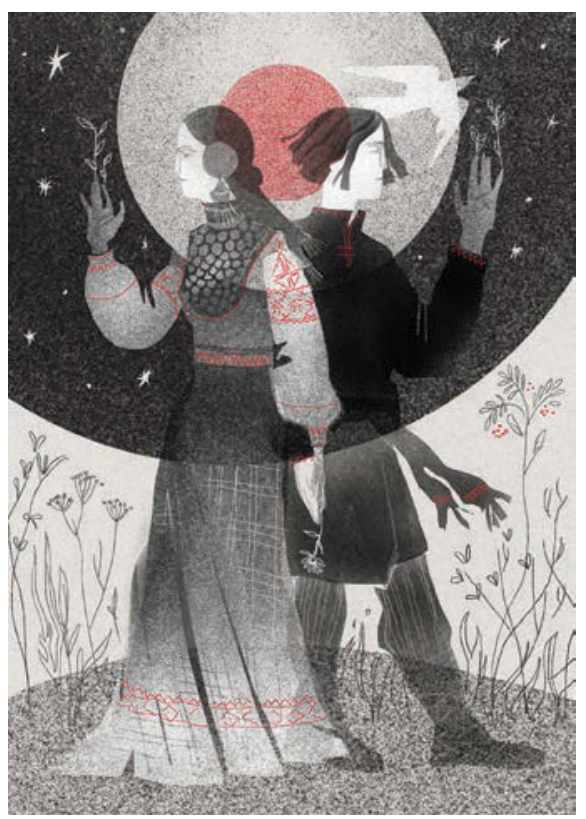



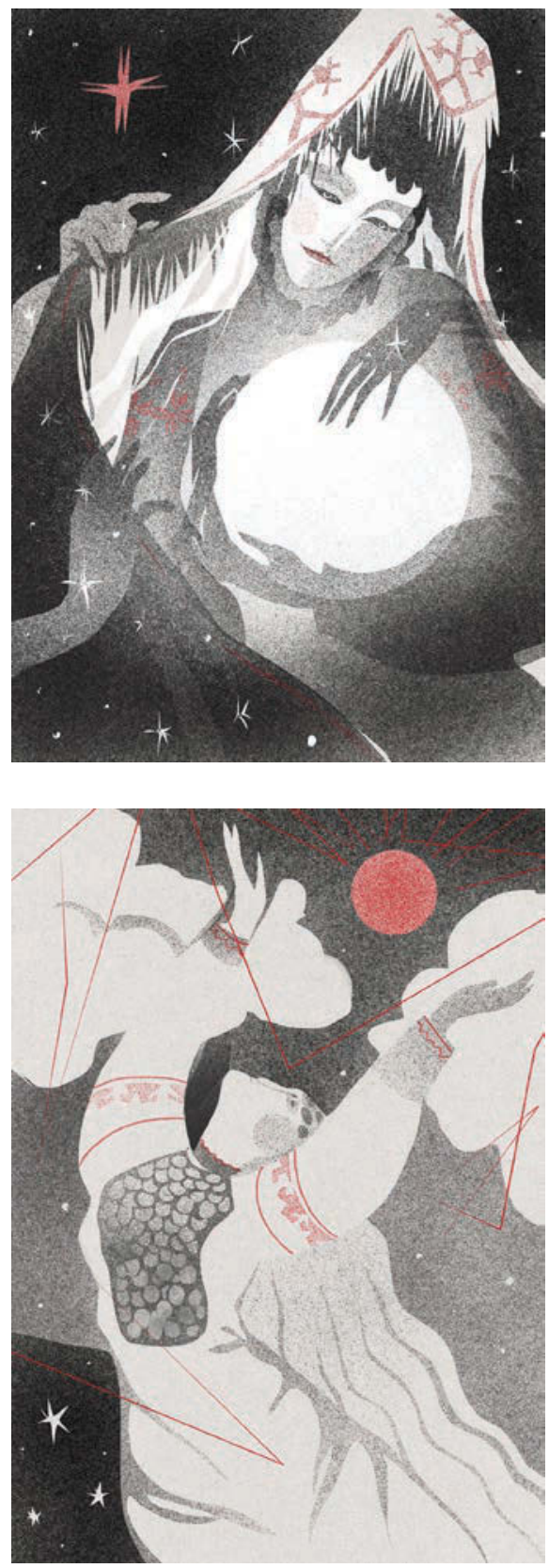

Tolez'-mumy. Computer generated image. Made by Ulyana Konstantinova (2021).
Shundy-mumy. Computer generated image. Made by Ulyana Konstantinova (2021). 
recorded in the $19^{\text {th }}$ century, generalised studies of which are presented by Vladimir Vladykin (Vladykin 1994).

The distinctive feature of Kildys'in, emphasised by modern researchers (Shutova 2014), is the number of different forms the deity has: creator of water, creator of the earth, keeper of the harvest, keeper of women. This plurality and multifunctionality of Kildys'in has become possible because of various multi-temporal layers.

Separate traits of this deity can be found in linguistic and folklore materials, representing additional argumentation in favour of one or other of its properties (Vladykina 2017). Today the expression "Kaltak! E, kaltak!", showing extreme annoyance at someone else's behaviour, has practically disappeared from everyday life. It is similar to the Russian expression “O Bozhe! O Gospodi?'. The only difference is that the Udmurt appeal to the mother ancestor Kaltak / Kaldyk Mumy, who has direct analogies with Koltesh among the Ugric people and their wish that someone be healthy as a result of 'rebirth'.

Kaltak seems to be the more ancient female hypostasis of Kyldys'in, who transferred to him her patronage of women in labour.

The concept of the merging of Kyldys'in with Vorshud, the ancestral deity, or mother-ancestor of a clan, has the same quality in our opinion. According to legend, during the summer this combined deity 'flies out' from the family sanctuary, the kuala, to the countryside and lives on the flowers. The Udmurts explain the reason for prayers in the summer in the countryside, rather than indoors, precisely because of this: vös' kyre pote, 'prayers go out / to freedom / to nature'. As an additional argument there is a set phrase, s'as'ka vylys' shed'tyny, 'found on flowers', meaning an illegitimate child. And if in Russian culture such a child is called 'wren, Udmurt mothers who have consciously had illegitimate children treated the children as gifts from above, from the mother-ancestor using the expression '[the child] was found on the flowers', which should be understood as 'the child was given by the mother-ancestor Kaltak / Kaldyk Mumy'.

Implicit semantic relationships such as mother-ancestorflowers-children can also be found, in our opinion, in separate 
local traditions among the Uva and Vavozh Udmurts, where the Trinity day commemorations were perceived as 'children's commemorations'. This means that dead children were remembered during the flowering season in spring.

In modern translations of the scripture, Kylchin-Inmar is a guardian angel. The complexity of the Kaldyk/Kaltak/Kyldys'in image, which combines feminine and masculine features, is connected, in our opinion, with the ancient androgynous essence of the deity. His qualitative characteristics are evolutionarily replenished with spatial parameters: Kyldys’in is localised in the sky, underground, and in water (Vladykina, Glukhova 2011).

The above images were, at a certain stage, able to perform the function of cosmological models, and were later replaced with detailed stories about mythological traditions and legends about the creation of the earth, man, and the establishment of customs. In etiological traditions, the motifs of the creation and the emergence of reality were revised in line with later traditions that had a predominance of moral and ethical attitudes, creating a peculiar synthesis of archaic narratives. One vivid example is the story about spots on the Moon (Vladykina 1998: 56-57). According to the belief, on the moon one can see an orphan girl with buckets and a shoulder yoke. She was sent for water by her evil stepmother at a freezing Christmas midnight. The girl decided to drown herself and jumped into the water. But, as the story says, "the water did not take her" (vu soye bas'tymte). Then the girl turned to the full moon begging for pity. And the moon took her to itself (ibidem). The narratives about the creation of the world that exist in the Udmurt tradition are related to biblical subjects and images, retold and modified in line with the national tradition through Russian / Old Believer (apocrypha) and Turkic mediation. Therefore, the legends about the creation of the world, man, and the reasons for the removal of heaven from the earth, have a lot in common with different cultures and create their own versions of the source material. 
We can say with a certain degree of probability that myths can reconstruct an imaginative system of spells and mantras and make use of a complex of artistic representations. But archaic mythologies, due to the perception of the world order/space, the Sun / tyr shundy, the Moon / tyr tolez', stars/kiz'il'i, the sky / in'yubo, the hub of the universe / muz"yemgogy, the beam that supports the earth / muz"yem közono were the guarantors of stability and eternal values. Spells have frozen the ideas about parallel - upper and lower/ underground - worlds, in which zoomorphic celestials live (the heavenly horse, the sun serpent, the golden-winged hawk), along with chthonic creatures, i.e. prototypes of water and underground elements (the water bull, the water horse,the gold-headed snake, the gold-headed toad with silver feet) (Vladykina 1998: 75-82).

Synthesizing examples of ritual practice, linguistic function and terminology provides an opportunity to expand Udmurt imagemythology and find the place in the religious and mythological picture of the world where mythological consciousness turns the world of the purely real into a system of absolute symbols.

\section{References}

Perevozchikova, T. 1982. Udmurtskiy fol'klor. Zagadki [Udmurt Folklore. Riddles]. Izhevsk: Udmurtia.

Shutova, N. 2014. Traditsionnoye udmurtskoye zhenskoye bozhestvo Kyldysin: Mnozhestvennost' obraza i napravleniya evolyutsii [Traditional Udmurt Female deity Kyldys'in: The Plurality of the Image and the Courses of Evolution]. Religiya $v$ istorii narodov Rossii i Tsentral'noy Azii: materialy II Mezhdunarodnoy konferentsii [Religion in History of the Peoples of Russia and Central Asia: Works of II International Conference]. Barnaul: Izd. Barnaul'skogo universiteta, pp. 366-370.

Vladykin, V. 1994. Religiozno-mifologicheskaya kartina mira udmurtov [The Udmurt's Religious and Mythological Worldview]. Izhevsk: Udmurtia. 
Vladykina, T. 1998. Udmurtskiy fol'klor: problemy zhanrovoy evolyutsii $i$ sistematiki [Udmurt Folklore: Problems of Genre Evolution and Systematisation]. Izhevsk: Udmurtskiy institut istorii, yazyka i literatury Uralskogo otdeleniya Rossiyskoy akademii nauk.

Vladykina, T. 2017. Lingvo-fol'klornyye metamorfozy Boga-Tvortsa $\mathrm{v}$ religiozno-mifologicheskoy kartine mira udmurtov [Linguistic and Folklore Metamorphoses of God the Creator in the Udmurt's ReligiousMythological Worldview]. XII Kongress antropologov i etnologov Rossii: Missiya antropologii $i$ etnologii: nauchnye traditsii $i$ sovremennyye vyzovy (3-6 iyulya 2017 g., Izhevsk) [XII Congress of Anthropologists and Ethnologists of Russia: The Mission of Anthropology and Ethnology: Scientific Traditions and Modern Challenges]. Izhevsk: Udmurtskiy universitet, p. 116.

Vladykina, T., Glukhova, G. 2011. Invu-mumy - povelitel'nitsa nebesnoy vlagi $\mathrm{v}$ traditsionnoy sisteme mirovideniya udmurtov [Invu-Mother the Goddess of Celestial Moisture in the Udmurt's Traditional Worldview]. Vestnik Udmurtskogo universiteta, Istoriya i filologiya [Bulletin of Udmurt University. History and Philology] 4, pp. 114-119.

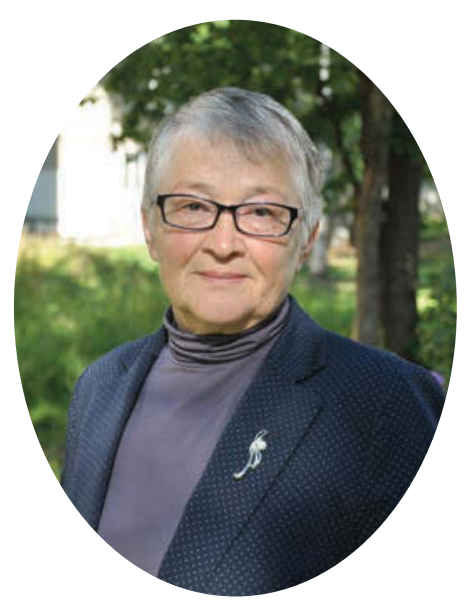

Tatiana Vladykina is ( $\mathrm{PhD}$ hab) a professor and leading researcher at the Udmurt Institute for Research in History, Language and Literature (Udmurt Federal Research Centre of the Ural Branch of the Russian Academy of Sciences). She has covered the range of topics in Udmurt folkloristics, especially mythology, specialising both in genre and in the treatment of the most important topics across genres.

e-mail: tgvladykina@mail.ru 